\title{
MANAJEMEN PENGADAAN GERAKAN SERIBU BUKU DI UIN ALAUDDIN MAKASSAR
}

\author{
La Ode Rusadi \\ Pascasarjana UIN Alauddin Makassar \\ Email: rusadilaode61̄gmail.com
}

\begin{abstract}
Abstrak: Proses manajemen pengadaan buku GSB UIN Alauddin Makassar ada beberapa tahapan, yang dimulai dari tahap pembentukan panitia GSB UIN Alauddin Makassar, pembukaan pendaftaran GSB UIN Alauddin Makassar, seleksi dan verifikasi berkas pendaftar GSB UIN Alauddin Makassar, pengumuman kelulusan pendaftaran GSB UIN Alauddin Makassar, dan tahap kontrak perjanjian. Tahapan manajemen pengadaan buku GSB UIN Alauddin Makassar menunjukkan sudah cukup baik dan terarah, akan tetapi masih perlu ada upaya-upaya evaluasi dan perbaikan, misalnya dari segi membangun hubungan kerjasama dan koordinasi di antara panitia, tim independen, dan penulis maupun evaluasi dan perbaikan yang sifatnya tekhnis.
\end{abstract}

\section{Keywords: Manajemen, pengadaan buku.}

\section{PENDAHULUAN}

Perkembangan jumlah buku pada era globalisasi ini setiap tahunnya semakin bertambah seiring dengan melimpahnya informasi yang dijadikan sebagai catatan pengetahuan oleh penulis buku. Di Indonesia setiap bulan menurut Dharma Hutauruk sebagaimana dikutip oleh Irsan, saat ini buku yang diterbitkan berkisar 1.500-2.000. Walaupun jumlah ini masih sangat kecil jika dikalkulasikan dengan total penduduknya yang terhitung 31 Desember 2010 mencapai 259.940 .857 orang. ${ }^{1}$

Dalam mengembangkan penerbitan buku di Indonesia diperlukan kerjasama dengan unsur-unsur perbukuan, seperti pengarang, percetakan, penerbit, penjual buku, kalangan pendidikan dan pustakawan yang dapat berbuat banyak untuk lebih meningkatkan peranan buku dalam masyarakat yang sedang membangun. Apalagi banyak kalangan mengatakan bahwa dalam hal perbukuan, Indonesia masih tertinggal dibandingkan dengan negara-negara lain, baik dalam jumlah judul, tiras, mutu isi dan tata rupa, luas penyebaran maupun pemanfaatan buku oleh masyarakat. ${ }^{2}$

Salah satu faktor yang menyebabkan Indonesia ketinggalan dari negara lain dalam penerbitan buku adalah kurangnya penulis. Di sisi lain, penerbitan buku terkendala oleh biaya dan pajak penerbitan buku mulai dari kertas, percetakan, penjilidan, sampai pada proses penyaluran yang cukup mahal. Hal tersebut berimplikasi pada masyarakat kesulitan mendapatkan bahan bacaan.

\footnotetext{
${ }^{1}$ Lihat Irsan, "Pandangan Pustakawan UIN Alauddin Makassar terhadap Pelarangan Buku- Buku Kiri di Era Orde Baru”, Skripsi, Makassar: Fakultas Adab dan Humaniora, 2013), h. 3.

${ }^{2}$ Koswara, Dinamika Informasi dalam Era Global (Bandung: Pengurus Daerah Ikatan Pustakawan Indonesia Jawa Barat bekerjasama dengan Penerbit PT Remaja Rosdakarya, 1998), h. 23.
} 
Demi meminimalisir potensi kurangnya bahan bacaan maka perguruan tinggi Universitas Islam Negeri Alauddin Makassar memotivasi dan menginstruksikan kepada para guru besar, dosen, mahasiswa, alumni, dan pegawai untuk melakukan perubahan dan memperbaiki sistem dan mutu pendidikan melalui budaya menulis. Hal ini dimaksudkan untuk memotivasi dan mendorong tercapainya visi dan tujuan UIN Alauddin Makassar dalam menjalankan amanah yang diembannya sebagai perguruan tinggi yang bermutu dan berkualitas. Tuntutan menulis dipandang begitu penting, sehingga dengan menulis maka minat belajar dan minat membaca mahasiswa juga akan meningkat. Pada dasarnya belajar memang tidak dapat lepas dari aktivitas membaca. Dalam Islam, wahyu yang pertama kali turun adalah perintah membaca. Sebagaimana tertuang dalam QS al-'Alaq /96: 1-5:

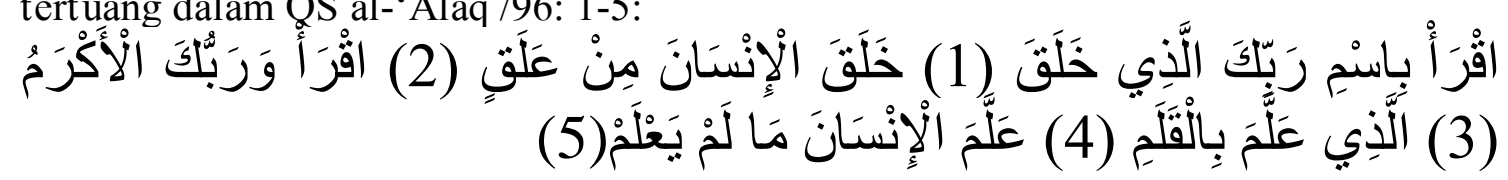

Terjemahnya:

Bacalah dengan (menyebut) nama Tuhanmu yang menciptakan; Dia telah menciptakan manusia dari segumpal darah. Bacalah, dan Tuhanmu-lah yang Maha pemurah. Yang mengajarkan (manusia) dengan perantaran kalam. Dia mengajarkan kepada manusia apa yang tidak diketahuinya. ${ }^{3}$

Ayat di atas menjelaskan tentang pentingnya membaca dalam kaitannya dengan kecerdasan dan menambah pengetahuan, maka setiap lembaga pendidikan, baik tingkat dasar, menengah maupun perguruan tinggi, baik swasta maupun negeri, harus senantiasa menyediakan kebutuhan pembelajaran yang kaitannya dengan ketersediaan buku.

Perguruan tinggi Islam seperti UIN Alauddin Makassar sudah mulai berbenah diri dengan melakukan berbagai strategi perubahan baik perubahan mental dari analog ke mental digital maupun perubahan fisik. Perubahan dalam bentuk fisik UIN Alauddin Makassar meluncurkan Gerakan Seribu Buku. Gerakan ini adalah bagian dari visi-misi Rektor sekaligus respon dari fenomena perkembangan peradaban intelektual masyarakat dan atas kehausan masyarakat terhadap kebutuhan informasi yang begitu pesat.

Di era sekarang masyarakat sangat membutuhkan informasi yang aktual, cepat dan efektif karena era teknologi informasi sangatlah penting untuk menjawab kebutuhan masyarakat yang ingin maju dan berkembang, serta ingin menguasai banyak ilmu pengetahuan yang tentunya dapat dilakukan dengan membaca/belajar pada buku dan sumber informasi lainnya.

Kehadiran gerakan seribu buku di UIN Alauddin Makassar mampu memberikan nuansa baru dalam memenuhi kebutuhan masyarakat atau pemustaka dalam mencari sumber informasi khususnya dalam lingkungan akademik. Untuk itu perlu mengetahui bagaiman manajemen pengadaan buku GSB bagi kelangsungan civitas akademika yang ada didalam satuan lingkup perguruan tinggi UIN Alauddin Makassar, mulai dari proses perencanaan, pemilihan, pengadaan, penerbitan sampai proses pemanfaatannya.

\footnotetext{
${ }^{3}$ Departemen Agama RI, Al-Qur'an dan Terjemahnya (Jakarta: Maghfirah Pustaka, 2006), h. 87.
} 


\section{KERANGKA TEORI}

\section{A. Pengertian manajemen}

Manajemen sering diartikan sebagai ilmu, kiat, dan profesi. Dikatan ilmu oleh Luther Gulick karena dipandang sebagai suatu bidang pengetahuan yang secara sistematik berusaha memahami mengapa dan bagaimana orang bisa bekerja sama. Dikatakan kiat oleh Follet karena manajemen mencapai sasaran melalui cara-cara dengan mengatur orang lain menjalankan tugas. Dipandang sebagai profesi karena manajemen dilandasi oleh keahlian khusus untuk mencapai suatu prestasi manajer, dan para profesional dituntut oleh suatu kode etik. ${ }^{4}$

Manajemen merupakan suatu bidang ilmu yang bersifat universal. Oleh karena itu, manajemen dapat diterapkan di seluruh bidang kehidupan dan penghidupan. Manajemen yang diterapkan di bidang perpustakaan disebut manajemen perpustakaan, manajemen yang diterapkan di bidang pemasaran disebut manajemen pemasaran, manajemen yang diterapkan pada penambahan koleksi disebut manajemen pengadaan dan pengembangan koleksi, demikian seterusnya.

Manajemen pada dasarnya merupakan suatu proses penggunaan sumber daya secara efektif untuk mencapai sasaran atau tujuan tertentu. Istilah manajemen biasa dikenal dalam istilah ilmu ekonomi, yang memfokuskan pada profit (keuntungan) dan komoditas komersial. Sama halnya dengan kata administrasi, kata manajemen juga berasal dari bahasa Latin, yaitu dari kata manus yang berarti tangan dan agree yang berarti melakukan. ${ }^{5}$ Kata-kata itu digabung menjadi kata kerja managare yang artinya menangani. Kemudian diterjemahkan ke dalam Bahasa Inggris dalam bentuk kata kerja to manage, dengan kata benda management, dan manager untuk orang yang melakukan kegiatan manajemen. Akhirnya, manajement diterjemahkan ke dalam Bahasa Indonesia menjadi manajemen atau pengelolaan.

Manajemen menurut Marbun sebagai penyelenggaraan koordinasi manusia dan fungsi-fungsi, hal mana dilakukan oleh manajer yang memimpin dan mengendalikan organisasi serta kegiatannya ke arah sasaran yang terpilih sebelumnya ${ }^{6}$.

Dalam konteks manajemen sumber daya manusia, secara fungsional manajemen meliputi perencanaan, pengorganisasian, pelaksanaan, dan evaluasi. Manajemen sebagai peranan antar pribadi memberi informasi dan pengambilan keputusan manajemen dapat pula berarti pengembangan keterampilan yaitu teknis, manusiawi dan konseptor.

Bagian dari tugas perguruan tinggi adalah menyiapkan, mengadakan, dan menyajikan informasi/buku untuk menunjang tercapainya tri dharma perguruan tinggi. Pengadaan buku harus mengikuti perkembangan ilmu pengetahuan, oleh karena itu buku yang disediakan harus sesuai dengan kebutuhan civitas akademika khususnya

${ }^{4}$ Lihat Nanang Fattah, Landasan Manajemen Pendidikan (Bandung: Remaja Rosdakarya, 2009), h. 1 .

${ }^{5}$ Husaini Usman, Manajemen: Teori Praktek dan Riset Pendidikan (Cet. II; Jakarta: Bumi Aksara, 2010), h. 5.

${ }^{6}$ B.N. Marbun, Konsep Manajemen Indonesia (Jakarta: Bagian Publikasi Lembaga Pendidikan dan Pembinaan Manajemen, 1980), h. 5.

${ }^{7}$ Faustino C. Gomes, Manajemen Sumber Daya Manusia (Yogyakarta: Andi Offset, 1997), h. 33. 
dosen dan mahasiswa. Dalam rangka penyediaan informasi/buku bagi dosen dan mahasiswa maka dikenal istilah pengadaan buku/pengembangan koleksi.

Visi pengadaan buku yaitu buku yang berkembang berdasarkan kebijakan yang tepat sejalan dengan perkembangan ilmu dan informasi serta meningkatkan mutu dosen dan mahasiswa sedangkan misi pengadaan buku yaitu menyusun dan menyediakan pedoman, petunjuk dan acuan yang rinci serta efektif untuk digunakan civitas akademika secara sistematis, tepat dan efisien.

Menurut William A. Shrode elemen-elemen dasar organisasi mencakup: (1) Tujuan; (2) Teknik; (3) Struktur; (4) Orang; (5) Informasi; Dari kelima tersebut memproses sejumlah input yang bersumber dari lingkungan dan output-nya digunakan oleh lingkungan. ${ }^{8}$

\section{B. Prinsip-Prinsip Manajemen}

\section{Perencanaan (planning)}

Merencanakan pada dasarnya menentukan kegiatan yang hendak dilakukan pada masa depan. Kegiatan ini dimaksudkan untuk mengatur berbagai sumber daya agar hasil yang dicapai sesuai dengan yang diharapkan.

Perencanaan adalah proses penentuan tujuan atau sasaran yang hendak dicapai dan menetapkan jalan dan sember yang diperlukan untuk mencapai tujuan itu seefisien dan seefektif mungkin. Dalam setiap perencanaan selalu terdapat tiga kegiatan yang meskipun dapat dibedakan, tetapi tidak dapat dipisahkan antara satu dengan yang lainnya dalam proses perencanaan. Kegiatan-kegiatan itu yaitu: (a) Merumuskan tujuan yang ingin dicapai; (b) Memilih program untuk mencapai tujuan; (c) Identifikasi dan pengerahan sumber yang jumlahnya terbatas.

Perencanaan selalu terkait dengan masa depan, dan masa depan selalu tidak pasti, banyak faktor yang berubah dengan cepat. Tanpa perencanaan, organisasi atau lembaga akan kehilangan kesempatan dan tidak dapat menjawab pertanyaan tentang apa yang akan dicapai, dan bagaimana mencapainya. Oleh karena itu, rencana harus dibuat agar semua tindakan terarah dan terfokus pada tujuan yang hendak dicapai. Perencanaan selalu dibuat oleh siapapun baik perseorangan maupun lembaga, baik lembaga bisnis, pemerintah maupun lembaga pendidikan.

perencanaan mengandung pokok-pokok pikiran berupa (1) perencanaan selalu berorientasi ke masa depan, maksudnya perencanaan berusaha meramalkan bentuk dan sifat masa depan yang diinginkan organisasi berdasarkan situasi dan kondisi masa lalu dan masa sekarang. (2) perencanaan merupakan sesuatu yang sengaja dilahirkan dan bukan kebetulan, sebagai hasil dari pemikiran yang matang dan cerdas yang bersumber dari hasil eksplorasi sebelumnya, (3) perencanaan memerlukan tindakan, baik oleh individu maupun organisasi yang melaksanakannya, dan (4) perencanaan harus bermakna, maksudnya dengan perencanaan usaha-usaha yang akan dilakukan dalam rangka mencapai tujuan yang telah ditetapkan sebelumnya menjadi lebih efektif dan efisien. $^{9}$

Dengan demikian, dapat disimpulkan bahwa perencanaan adalah persiapan menyusun suatu keputusan berupa langkah-langkah penyelesaian suatu masalah atau pelaksanaan suatu pekerjaan yang terarah pada pencapaian tujuan tertentu. Di dalam

\footnotetext{
${ }^{8}$ Lihat Nanang Fattah, Landasan Manajemen Pendidikan, h. 29-30.

${ }^{9}$ Marno dan Triyo Supriyatno, Teknologi Informasi Perpustakaan, h. 14.
} 
bidang pendidikan, perencanaan dimaksudkan sebagai persiapan menyusun keputusan tentang masalah atau pekerjaan yang akan dilaksanakan oleh sejumlah orang dalam rangka membantu orang lain terutama peserta didik untuk mencapai tujuan pendidikan. a. Pengorganisasian (organizing)

Kegiatan manajemen terutama dari aspek administratifnya tidak berakhir setelah perencanaan tersusun. Kegiatan selanjutnya adalah melaksanakan perencanaan itu secara operasional. Salah satu kegiatan administratif manajemen mengaplikasikan suatu rencana disebut organisasi atau pengorganisasian. Oleh karena itu, tidak mengherankan jikalau beberapa ahli manajemen menempatkan fungsi pengorganisasian setelah fungsi perencanaan. Penempatan fungsi pengorganisasian setelah fungsi perencanaan merupakan hal logis karena tindakan pengorganisasian menjembatani kegiatan perencanaan dengan pelaksanaannya.

Tanpa pengorganisasian mustahil suatu rencana dapat mencapai tujuan, tanpa pengorganisasian para pelaksana tidak memiliki pedoman kerja yang jelas dan tegas sehingga pemborosan dan tumpang tindih akan mewarnai pelaksanaan suatu rencana yang akibatnya adalah kegagalan dalam mencapai tujuan. Pengorganisasian diartikan sebagai kegiatan pembagi tugas-tugas pada orang yang terlibat dalam kerjasama di suatu organisasi atau kelembagaan seperti madrasah. Karena tugas-tugas tersebut tidak dapat dikerjakan dan diselesaikan hanya seorang saja, melainkan dibagi untuk dikerjakan oleh masing-masing unit organisasi.

Di dalam organisasi atau lembaga termasuk lembaga pendidikan ada sejumlah orang, baik sebagai manajer maupun sebagai anggota, ada struktur, tujuan-tujuan, aturan dan prosedur. Orang yang melaksanakan manajemen inilah yang disebut dengan manajer, dan yang melaksanakan pekerjaan praktis adalah anggota. Dengan demikian, organisasi atau lembaga terdiri dari beberapa unsur, yaitu (1) ada kumpulan orangorang, (2) ada pembagian kerja atau spesialisasi dalam organisasi, (3) bekerjasama di mana aktivitas-aktivitas yang terpisah dikoordinir, dan (4) ada tujuan bersama yang akan dicapai melalui kerjasama yang terkoordinir. ${ }^{10}$

Sementara itu, Marno dan Triyo Suprayitno, mengemukakan bahwa organisasi adalah struktural yang mengikat atau menyatukan unsur-unsur sebagai berikut:

1. Manusia (human factor) berupa unsur manusia yang bekerjsama, ada pimpinan dan ada yang dipimpin, dan seterusnya.

2. Sasaran, yakni tujuan yang ingin dicapai.

3. Tempat kedudukan di mana manusia memainkan peran, wewenang dan tugasnya.

4. Pekerjaan dan wewenang sesuai dengan peran dan kedudukannya yang disusun dalam pembagian tugas (job description).

5. Teknologi, yakni berupa hubungan antara manusia yang satu dengan yang lain sehingga tercipta organisasi.

6. Lingkungan, yakni adanya lingkungan yang saling mempengaruhi, seperti adanya sistem kerja sama sosial. ${ }^{11}$

\section{b. Penggerakan (Actuating)}

Penggerakan pada dasarnya merupakan fungsi manajemen yang kompleks dan ruang lingkupnya cukup luas serta berhubungan erat dengan sumber daya manusia. Penggerakan merupakan salah satu fungsi terpenting dalam manajemen. Urgennya

\footnotetext{
${ }^{10}$ Syafaruddin, Manajemen Lembaga Pendidikan Islam (Jakarta: Ciputat Press, 2005), h. 70.

${ }^{11}$ Marno dan Triyo Supriyatno, Teknologi Informasi Perpustakaan, h. 18.
} 
pelaksanaan penggerakan didasarkan pada alasan bahwa usaha-usaha perencanaan dan pengorganisasian bersifat vital tapi tak aka nada outputnya yang kongkrit yang dihasilkan tanpa adanya implementasi dan aplikasi aktivitas yang diusahakan dan diorganisasikan dalam suatu tindakan actuating atau usaha yang menimbulkan action. Oleh karena itu, Hasibuan menganggap bahwa penggerakan merupakan fungsi yang terpenting dalam manajemen. ${ }^{12}$

Penggerakan adalah hubungan erat antara aspek-aspek individual yang ditimbulkan dari adanya pengaturan terhadap bawahan untuk dapat dimengerti dan pembagian kerja yang efektif dan efisien untuk mencapai tujuan perusahaan yang nyata. ${ }^{13}$ Rumusan pengertian penggerakan yang agak berbeda dirumuskan Terry dalam Marno dan Triyo Supriyatno bahwa actuating sebagai usaha menggerakkan anggota kelompok sedemikian rupa hingga mereka berkeinginan dan berusaha untuk mencapai sasaran perusahaan yang bersangkutan dan sasaran anggota perusahaan, karena para anggota itu ingin mencapai sasaran-sasaran tersebut. ${ }^{14}$

Kedua persepsi di atas memberikan kejelasan bahwa penggerakan adalah kegiatan untuk mengarahkan orang lain agar suka dan dapat bekerja dalam upaya mencapai tujuan. Pada definisi di atas terdapat penekanan tentang keharusan cara yang tepat digunakan untuk menggerakkan yaitu cara memotivasi atau memberi motif-motif bekerja kepada bawahannya agar mau dan senang melakukan segala aktivitas dalam rangka mencapai tujuan secara efektif dan efisien.

c. Pengendalian (Controlling)

Pengendalian merupakan suatu unsur manajemen untuk melihat apakah segala kegiatan yang dilaksanakan telah sesuai dengan rencana yang digariskan dan di samping itu merupakan hal yang penting untuk menentukan rencana kerja yang akan datang. Oleh karena itu, pengawasan merupakan suatu kegiatan yang perlu dilakukan oleh setiap pelaksana terutama yang memegang kendali jabatan pimpinan. Tanpa control, pimpinan akan sulit melihat dan mengendalikan kemungkinan terjadinya penyimpangan-penyimpangan.

Marno dan Triyo Suprayitno, menyebutkan beberapa unsur yang perlu diketahui dalam proses pengendalian sebuah organisasi, yakni:

1) Adanya proses dalam menetapkan pekerjaan yang telah dan akan dikerjakan.

2) Merupakan alat untuk menyuruh orang bekerja menuju sasaran-sasaran yang ingin dicapai.

3) Memonitor, menilai, dan mengoreksi pelaksanaan pekerjaan.

4) Menghindarkan dan memperbaiki kesalahan, penyimpangan atau penyalahgunaan, dan

5) Mengukur tingkat efektivitas dan efisiensi kerja. ${ }^{15}$

Penguraian singkat di atas dapat dipahami bahwa pengendalian dapat dilakukan melalui tahap-tahap yang telah ditentukan berdasarkan perencanaan yang telah disusun sebelumnya. Tahap-tahap yang dimaksud adalah menentukan standar atau dasar untuk melakukan control, mengukur pelaksanaan kerja, membandingkan pelaksanaan dengan

${ }^{12}$ Hasibuan, Manajemen Dasar Pengerian dan Masalah (Edisi I; Cet. II; Bandung: Haji Masagung, 1990), h. 25.

${ }^{13}$ Marno dan Triyo Supriyatno, Teknologi Informasi Perpustakaan, h. 29.

${ }^{14}$ Marno dan Triyo Supriyatno, Teknologi Informasi Perpustakaan, h. 21.

${ }^{15}$ Marno, Trio Supriyanto. Teknologi Informasi Perpustakaan, h. 25. 
standar dan menentukan deviasi-deviasi bila terjadi atau ada, dan melakukan tindakan perbaikan jika terdapat penyimpangan (deviasi) agar pelaksanaan dan tujuan sesuai dengan rencana atau harapan.

Dengan demikian, terdapat empat fungsi-fungsi manajemen menurut Marno dan Triyo Supriyatno, yakni (1) perencanaan (planning), (2) pengorganisasian (Organizing), (3) penggerakan (Actuatin), (4) pengendalian (Controlling).

e. Evaluasi (Evaluation)

Kata evaluasi berasal dari bahasa Inggris evaluation yang berarti penilaian atau penaksiran. ${ }^{16}$ Evaluasi adalah suatu kegiatan sistematis dan terencana untuk mengukur, menilai dan klasifikasi pelaksanaan dan keberhasilan program. ${ }^{17}$ Dalam suatu organisasi penggunaan evaluasi sangatlah penting guna untuk menilai akuntabilitas organisasi. Penilaian ini bisa menjadi netral, positif atau negatif atau merupakan gabungan dari keduanya. Saat sesuatu dievaluasi biasanya orang yang mengevaluasi mengambil keputusan tentang nilai atau manfaatnya.

Evaluasi bertujuan untuk menjamin mencapaian sasaran serta tujuan perusahaan. Selain itu tujuan evaluasi untuk mengetahui posisi organisasi serta pencapaian yang telah diraih oleh karyawan. evaluasi ini sangat berguna untuk mengetahui adanya ketidak beresan yang terjadi pada organisasi. Misalnya untuk mengetahui keterlambatan atau penyimpangan yang telah terjadi, setelah di evaluasi maka akan di ketahui semua penyimpangan itu dan dapat segera diperbaiki sehingga tujuan perusahaan dapat tercapai dengan optimal.

Selain itu tujuann evaluasi juga untuk menjamin pencapaian sasaran dan tujuan organisasi dan juga untuk mengetahui posisi organisasi dan tingkat pencapaian sasaran organisasi, terutama untuk mengetahui bila terjadi keterlambatan atau penyimpangan supaya segera diperbaiki, sehingga sasaran atau tujuan tercapai.

Fungsi evaluasi untuk memberi informasi yang baik dan benar. Memberi kritikan pada klarifikasi suatu nila-nilai dari suatu tujuan dan target, kemudian membuat suatu metode kebijakan untuk mencapai kinerja sehingga program dan kegiatan yang di evaluasi memberikan kontribusi bagi perumusan ulang kebijakan suatu kegiatan dalam organisasi atau instansi.

Tahap dan proses pelaksanaan evaluasi yaitu, 1) Penilaian pada tahap awal program: Dilakukan ketika program belum dilaksanakan. Untuk menentukan skala prioritas dari berbagai alternative dan kemungkinan cara mencapai tujuan yang telah dirumuskan sebelumnya. 2) Penilaian pada tahap pelaksanaan program: Dilakukan ketika program telah dilaksanakan. Untuk menentukan tingkat kemajuan pelaksanaan rencana dibandingkan dengan rencana sebelumnya. 3) Penilaian pada tahap akhir program: Dilakukan ketika program telah selesai dilaksanakan, untuk mereview apakah pencapaian program mampu mengatasi masalah yang ingin diciptakan, untuk menilai efisiensi, efektifitas terhadap pencapaian program tersebut.

Bertolak dari seluruh rangkaian pembahasan di atas, maka dapat disimpulkan bahwa fungsi-fungsi manajemen secara manajerial adalah Pertama berfungsi Planning atau perencanaan merupakan pemilihan atau penetapan tujuan-tujuan organisasi dan penentuan strategi kebijaksanaan proyek program prosedur metode sistem anggaran

\footnotetext{
${ }^{16}$ Anas Sudijono, Pengantar Evaluasi Pendidikan (Cet. III; Jakarta: PT. Grafindo Persada, 2001), h. 1.

${ }^{17}$ Suharsimi Arikunto, Evaluasi Program Pendidikan: Pedoman Teoritis Praktis Bagi Praktisi Pendidikan (Cet. I; Jakarta: Bumi Aksara, 2004), h. 25.
} 
dan standar yang dibutuhkan untuk mencapai tujuan. Kedua, organizing atau pengorganisasian ini meliputi: penentuan sumber daya dan kegiatan-kegiatan yang dibutuhkan untuk mencapai tujuan organisasi, perancangan dan pengembangan suatu organisasi atau kelompok kerja yang akan dapat membawa hal-hal tersebut ke arah tujuan, penugasan tanggung jawab tertentu, dan pendelegasian wewenang yang diperlukan kepada individu-individu untuk melaksanakan tugasnya.

Ketiga Penggerakan atau acctuating adalah kegiatan untuk mengarahkan orang lain agar suka dan dapat bekerja dalam upaya mencapai tujuan. Keempat controlling atau pengawasan adalah penemuan dan penerapan cara dan alat untuk menjamin bahwa rencana telah dilaksanakan sesuai dengan yang telah ditetapkan. Kelima, evaluation atau evaluasi adalah suatu kegiatan sistematis dan terencana untuk mengukur, menilai dan klasifikasi pelaksanaan dan keberhasilan program. Dalam suatu organisasi penggunaan evaluasi sangatlah penting guna untuk menilai akuntabilitas organisasi. Penilaian ini bisa menjadi netral, positif atau negatif atau merupakan gabungan dari keduanya. Saat sesuatu dievaluasi biasanya orang yang mengevaluasi mengambil keputusan tentang nilai atau manfaatnya.

\section{Manajemen pengadaan buku}

Pengadaan merupakan terjemahan dari aquisition, yaitu kegiatan yang merupakan implementasi dan keputusan dalam melakukan seleksi yang mencakup semua kegiatan untuk mendapatkan bahan pustaka/buku yang telah dipilih dengan cara membeli, tukar-menukar, hadiah, atau dengan cara menerbitkan sendiri. ${ }^{18}$ Begitupun juga menurut Soetminah pengadaan koleksi adalah proses menghimpun bahan pustaka yang akan dijadikan koleksi suatu perpustakaan. ${ }^{19}$

Menurut Darmono pengadaan bahan pustaka adalah pembinaan koleksi yang berarti kegiatan memilih pustaka atau bahan untuk perpustakaan, kemudian menetapkan dan mengadakan koleksi perpustakaan. ${ }^{20}$ Sedangkan Menurut Sulistyo Basuki mengemukakan bahwa pengadaan bahan pustaka merupakan konsep yang mengacu pada prosedur sesudah kegiatan pemilihan bahan untuk memperoleh dokumen yang diinginkan. ${ }^{21}$

Dalam proses transfer informasi/mendapatkan bahan pustaka maka Evans dalam defeloping library and information center collection dapat digambarkan sebagai proses kegiatan yang berkesinambungan, yang terdiri dari 9 komponen kegiatan, yaitu sebagai berikut: (1) Identifikasi; (2) Seleksi; (3) Pengadaan; (4) Organisasi; (5) Pengolahan; (6) Penyimpanan; (7) Interpretasi; (8) Pemanfaatan; (9) Penyebaran. ${ }^{22}$ Proses perputaran transfer informasi tersebut diawali dari tahap identifikasi, yaitu suatu kegiatan untuk memilah antara informasi yang tepat dengan yang tidak tepat.

Dalam proses pengembangan dan pengadaan buku di perguruan tinggi, maka perlu kiranya dijelaskan cakupan bahan bacaan/buku yang sesuai dengan kebutuhan civitas akademika. Pada perguruan tinggi ketersediaan bahan bacaan yang baik dan

\footnotetext{
${ }^{18}$ Hildawati Almah, Pemilihan dan Pengembangan Koleksi Perpustakaan, (Makassar: Alauddin University Press, 2012), h. 79.

${ }^{19}$ Soetminah, Perpustakaan, Kepustakawanan dan Pustakawan, (Yogyakarta: Kanisius, 1992), h. 71.

${ }^{20}$ Darmono, Manajemen dan Tata Kerja Perpustakaan Sekolah (Jakarta: Gramedia Pustaka Utama, 2001), h. 55.

${ }^{21}$ Sulistyo-Basuki, Pengantar Ilmu Perpustakaan (Jakarta: Gramedia Pustaka utama, 2000), h. 27.

${ }^{22}$ Yulia Yuyu, dkk. Pengelolaan Bahan Pustaka (Jakarta: Universitas Terbuka, 2009), h. 13.
} 
memadai melalui wadah perpustakaan harus disesuaikan dengan standar koleksi perpustakaan perguruan tinggi. Dengan hal itu sehingga dapat menunjang pelaksanaan program pendidikan, pengajaran, penelitian, dan pengabdian pada masyarakat.

Dalam buku Pedoman Umum Perpustakaan Perguruan Tinggi yang termasuk komponen koleksi perpustakaan perguruan tinggi, adalah:

1. Buku teks, baik untuk mahasiswa maupun untuk dosen, baik yang diwajibkan maupun yang dianjurkan untuk mata kuliah tertentu.

2. Buku referensi, termasuk buku referensi umum, referensi bidang studi khusus, alat-alat bibliografi, seperti indeks, abstrak, laporan tahunan, kamus, ensiklopedia, katalog, buku pegangan, dan sebagainya.

3. Pengembangan ilmu, yang melengkapi dan memperkaya pengetahuan pemustaka selain dari bidang studi dasar.

4. Penerbitan berkala, majalah, surat kabar, dan lainnya.

5. Penerbitan Perguruan Tinggi, yaitu penerbitan yang diterbitkan oleh perguruan tinggi, baik perguruan tinggi dimana perpustakaan tersebut bernaung maupun penerbitan perguruan tinggi lainnya.

6. Penerbitan pemerintah, yaitu penerbitan resmi baik yang besifat umum maupun yang menyangkut kebutuhan perguruan tinggi yang bersangkutan.

7. Koleksi khusus, yang berhubungan dengan minat khusus perpustakaan, seperti koleksi tentang kebudayaan daerah tertentu, subjek tertentu dan lain sebagainya.

8. Koleksi bukan buku, yaitu berupa koleksi audio visual seperti film, tape, kaset, piringan hitam, video tape dan sebagainya. ${ }^{23}$

Dari beberapa pengertian di atas dapat dipahami bahwa sistem kebijakan pengadaan koleksi adalah suatu metode atau proses untuk menghimpun, memilih dan menetapkan bahan pustaka yang akan dijadikan koleksi suatu perpustakaan.

\section{Pemilihan Buku/Bahan Pustaka}

Langkah awal dari pengadaan koleksi bahan pustaka adalah melakukan penelitian mengenai kebutuhan pengguna. Untuk mengetahui kebutuhan pemustaka tersebut informasi yang perlu dikumpulkan adalah semua informasi yang dibutuhkan dari seluruh lapisan masyarakat. Berbekal hasil penelitian mengenai kebutuhan pengguna, pemilihan atau seleksi bahan dapat dilaksanakan. Dalam melakukan pemlihan hendaknya perpustakaan mempunyai kebijaksanaan ini didasarkan pada prinsip-prinsip:

1. Pemilihan di lakukan dengan cermat oleh pihak yang berwenang memilih berdasarkan skala prioritas.

2. Pengadaan koleksi disesuaikan dengan program pendidikan yang dimiliki oleh perguruan tinggi yang bersangkutan.

3. Bahan yang dipilih disesuaikan dengan kebutuhan pengguna yang terdiri dari mahasiswa, dosen, peneliti, dan pegawai administrasi.

4. Koleksi hendaknya lengkap, tidak hanya buku ajar wajib, tetapi juga meliputi bahan-bahan yang berkaitan dengan program pendidikan dan penelitian.

5. Bahan yang diadakan diusahakan bersifat mutakhir sesuai dengan perkembangan ilmu pengetahuan.

\footnotetext{
${ }^{23}$ Departemen Pendidikan Nasional RI Direktorat Jenderal Pendidikan Tinggi, "Perpustakaan Perguruan Tinggi; Buku Pedoman", (Jakarta: Departemen Pendidikan Nasional RI, 2005), h. 112.
} 


\section{Ketentuan Dalam Memilih Buku/Bahan Pustaka}

Dengan adanya perkembangan ilmu pengetahuan dan teknologi maka makin berkembang pula jenis dan bahan pustaka, sehingga untuk membangun koleksi perpustakaan perlu dilakukan seleksi, karena tidak mungkin sebuah perpustakaan bagaimanapun besarnya akan menghimpun semua bahan pustaka yang ada Pemilihan bahan pustaka adalah kegiatan dalam memilih judul-judul bahan pustaka yang akan dipergunakan sebagai koleksi bahan pustaka. Ketentuan dalam memilih bahan pustaka antara lain:

a. Harus disesuaikan dengan kebutuhan dan permintaan dari para pengguna.

b. Dalam melayani kebutuhan dan permintaan masyarakat pemakai tidak boleh didasarkan pada perbedaan golongan, politik, sosial dan budaya.

c. Bahan pustaka yang dipilih harus dapat dimanfaatkan oleh pemakai dalam menambah wawasan ilmu pengetahuan.

d. Bahan pustaka yang dipilih untuk dijadikan koleksi, terlebih dahulu harus dilihat dari segi isi, pengarang, tahun keluaran dan sifat fisiknya, serta sesuai dengan katalog penerbit, yang terdiri dari:

1) Tenaga Pelaksana Pemilihan

Tenaga yang melakukan pemilihan hendaknya dipilih dari orang-orang yang memahami kebutuhan pengguna perpustakaan antara lain lapisan masyarakat seperti dosen, spesialis subyek, peneliti, dan mahasiswa.

2) Alat-alat Pemilihan dan Verifikasi

Pemilihan bahan pustaka dapat dilakukan dengan mempergunakan berbagai alat pemilihan sebagai berikut:

(a)Bibliografi subyek khusus

(b)Daftar tambahan koleksi (accession list) perpustakaan lain

(c) Timbangan buku

(d)Masukan dari pengguna buku perpustakaan

Disamping itu, perpustakaan dapat memanfaatkan berbagai alat verifikasi sebagai sarana bantu identifikasi bahan pustaka sebagai berikut:

1. Katalog penerbit terbaru

2. Bibliografi nasional maupun internasional

3. Iklan dalam surat kabar atau majalah

Dengan kemajuan teknolagi sekarang ini, Pangkalan Data Penerbit yang dapat diakses melalui internet digunakan sebagai sarana bantu pemilihan dan verifikasi.

\section{METODOLOGI PENELITIAN}

\section{Jenis Penelitian}

Jenis penelitian ini adalah penelitian deskriptif ${ }^{24}$ kualitatif $^{25}$ untuk memahami dan menelaah masalah-masalah dalam hal ini adalah manajemen pengadaan GSB di

\footnotetext{
${ }^{24}$ Penelitian deskriptif bertujuan untuk membuat deskripsi yaitu gambaran atau lukisan secara sistematis, faktual dan aktual mengenai fenomena atau hubungan antara fenomena yang diselidiki. Lihat Imam Suprayogo, Metodologi Penelitian Sosial-Agama (Cet. I; Bandung: PT Remaja Rosdakarya, 2001), h. 137.

${ }^{25}$ Penelitian kualitatif menggunakan paradigma alamiah yang mengasumsikan bahwa kenyataan empiris terjadi dalam suatu konteks sosio-kultural yang saling terkait satu sama lain. Lihat Sayuthi Ali, Metodologi Penelitian Agama: Pendekatan Teori dan Praktek, Ed. I (Cet. I; Jakarta: PT Raja Grafindo Persada, 2002), h. 59.
} 
UIN Alauddin Makassar. Lokasi penelitian yang berkaitan dengan pembahasan tersebut adalah di Universitas Islam Negeri Alauddin Makassar yang terletak di Jalan H. Muh. Yasin Limpo, Romang Polong, Kabupaten Gowa.

Pendekatan yang penulis gunakan dalam penelitian ini adalah pendekatan kualitatif dengan pertimbangan bahwa di UIN Alauddin Makassar telah mencanangkan program pengadaan gerakan seribu buku. Penelitian ini mengkaji tentang manajemen program pengadaan gerakan seribu buku UIN Alauddin Makassar. Objek penelitian yang dijadikan sebagai informan dalam mengumpulkan data terdiri atas beberapa komponen, yaitu Wakil Rektor I, pengelola lembaga Penjaminan Mutu, ketua panitia GSB UIN Alauddin Makassar, dosen, dan mahasiswa. Sedangkan sumber data yang lain yang sifatnya non-insani adalah berupa dokumen-dokumen penting yang berkaitan dengan penelitian.

Dalam penelitian ini penulis menggunakan beberapa metode pengumpulan data, yaitu: observasi, interview, dan dokuemntasi. Instrumen penelitian yang digunakan adalah catatan observasi, pedoman wawancara, dan cek list dokumentasi. Data yang diperoleh melalui teknik tersebut diolah oleh penulis dengan menggunakan metode sebagai berikut:

1) Menyusun suatu daftar permasalahan dalam bentuk pertanyaan dan disusun secara sistematis berdasarkan kerangka konseptual.

2) Menguraikan setiap pertanyaan untuk selanjutnya disusun menurut kebutuhan data dan berbagai perkiraan jawaban yang mungkin akan diberikan oleh para informan.

3) Mencantumkan suatu kode (coding) pada setiap pertanyaan bersamaan dengan jawaban dan informasi yang dilontarkan atau diberikan oleh para informan. Tanda tersebut berupa nama, status informan atau jawaban singkat. Ini dimaksudkan agar memudahkan pelacakannya termasuk untuk keperluan interpretasinya nanti.

4) Mengkaji setiap pertanyaan berikut kode dan keterangan jawaban yang hendak diintepretasi dalam bahasa baku menurut perspektif penulis.

5) Formulasi-formulasi yang telah dirumuskan sedemikian rupa tersebut, dituangkan ke dalam susunan yang saling berangkai dalam bentuk pertanyaan deskriptif yang siap disajikan sebagai sebuah pembahasan tesis yang representative.

Model analisis data yang digunakan dalam penelitian ini adalah model interaktif yang dikembangkan oleh Miles dan Huberman yang dimulai dengan pengumpulan data, reduksi data, penyajian data, dan penarikan kesimpulan/verifikasi. ${ }^{26}$ Proses analisis data dilakukan secara terus-menerus di dalam proses pengumpulan data selama penelitian berlangsung.

\section{HASIL PENELITIAN DAN PEMBAHASAN}

Bagian dari tugas perguruan tinggi adalah menyiapkan, mengadakan, dan menyajikan informasi/buku untuk menunjang tercapainya tri dharma perguruan tinggi. Pengadaan buku harus mengikuti perkembangan ilmu pengetahuan, oleh karena itu buku yang disediakan harus sesuai dengan kebutuhan civitas akademika khususnya dosen dan mahasiswa. Dalam rangka penyediaan informasi/buku bagi dosen dan mahasiswa maka dikenal istilah pengadaan buku/pengembangan koleksi.

Dalam hal menunjang tercapainya Tri Dharma Perguruan Tinggi, maka UIN Alauddin Makassar mencanangkan program gerakan seribu buku. Dengan berprinsip

\footnotetext{
${ }^{26}$ Wahyu, Pedoman Penelitian Pendidikan (Bandung: Tarsito, 1996), h. 61.
} 
pada fungsi-fungsi manajemen secara manajerial yaitu Planning/perencanaan, organizing/pengorganisasian, actuatingPenggerakan, controlling/pengawasan, dan evaluation/evaluasi.

Berdasarkan penuturan Zulfahmi Alwi yang mengungkapkan bahwa untuk menghasilkan buku yang sesuai dengan tuntutan perkembangan ilmu pengetahuan maupun sesuai dengan kebutuhan mahasiswa maka dilakukan proses yang begitu teliti oleh tim independen, dimana setiap satu proposal diseleksi oleh 2 orang tim independen yang profesional dan representatif sesuai bidang keilmuannya. Dari hasil seleksi itu maka akan dilakukan verifikasi dari 2 orang penilai siapa yang tertinggi poinnya maka itulah yang akan lulus denga penilaian yang proporsional. Untuk menyeleksi atau menguji apakah buku itu layak atau tidak untuk diterima oleh pihak pengelola program GSB UIN Alauddin Makassar, maka diperkuat juga melalui sosialisasi kriteria buku yang akan diterima, diantaranya menunjang buku daras, menunjang perkuliahan, menunjang perkembangan ilmiah dibidang ilmu yang dikaji. ${ }^{27}$

Sedangkan dari hasil observasi penulis, bahwa langkah-langkah yang dilakukan dalam proses pengadaan buku GSB UIN Alauddin Makassar, yaitu:

\section{Pembentukan Panitia GSB UIN Alauddin Makassar :}

a. Panitia terbagi atas 2 yaitu tim independen dan tim biasa

b. Masing-masing panitia saling berkoordinasi

c. Setiap panitia memiliki tugas dan fungsi masing-masing

\section{Pembukaan Pendaftaran GSB UIN Alauddin Makassar :}

a. Sosialisasi pendaftaran melalui: spanduk, dan website UIN Alauddin (www.uinalauddin.ac.id)

b. Kategori pendaftar: Guru Besar, Dosen, Pegawai, Mahasiswa, dan Alumni

c. Proses pendaftaran:

1) Demi untuk meningkatkan kualitas layanan dan proses penjaminan mutu, sistem registrasi Pengajuan Proposal Penulisan Buku dalam Rangka Gerakan Seribu Buku dirancang secara online.

2) Melalui registrasi online pendaftar akan diverifikasi oleh panitia.

3) Untuk melakukan registrasi, peserta harus menempuh beberapa tahapan sebagai berikut:

a) Mengunjungi website: http://www.uin-alauddin.ac.id atau langsung pada http://gsb.uin-alauddin.ac.id.

b) Mengakses Pendaftaran online Pengajuan Proposal Penulisan Buku 'Gerakan Seribu Buku'.

c) Mengisi Formulir Pendaftaran dengan lengkap dan benar. Peserta hanya bisa mendaftar 1 (satu) kali untuk Program Gerakan Seribu Buku Tahun 2014 ini.

d) Setelah berhasil mengisi Formulir Pendaftaran, data anda akan di verifikasi oleh Panitia.

4) Registrasi online dan uploading proposal dan naskah buku memiliki batas akhir sesuai ketentuan dari panitia GSB UIN Alauddin Makassar.

\section{Seleksi dan Verifikasi Berkas Pendaftar GSB UIN Alauddin Makassar}

a. Proses Seleksi

\footnotetext{
${ }^{27}$ Zulfahmi Alwi, Sekretaris Program Gerakan Seribu Buku UIN Alauddin Makassar, wawancara, Samata, tanggal 19 Juni 2015.
} 
Penyeleksian pendaftar dilakukan secara terbuka dan profesional, dari jumlah pendaftar yang melebihi kuota akan diseleksi dengan teliti sampai memenuhi batas kuota yang diinginkan, pendaftar yang kurang cermat memahami dan mempelajari petunjuk pengajuan proposal penulisan buku maka sangat beresiko akan didiskualifikasi secara otomatis, dan keterlambatan peserta mendaftar sesuai target waktu yang ditetapkan maka sangat beresiko akan gugur berkas.

b. Verifikasi berkas

Dalam rangka penyusunan proposal buku karya ilmiah UIN Alauddin Makassar yang berkualitas, maka dipandang perlu untuk memverifikasi berkas pendaftar diantaranya:

1) Pengecekan keabsahan berkas pendaftar

2) Format proposal, yaitu:

Sistematika proposal (singkat) buku yang diajukan adalah:

a. Proposal Penulisan Buku disusun tidak lebih dari 7 (tujuh) halaman yang

diketik pada kertas ukuran A4; spasi 1,5 lines; huruf Times New Roman size 12 point; margin 2,5 cm.

b. Proposal Penulisan Buku berisi beberapa bagian sebagai berikut:

1) Halaman Cover; berisi, judul buku, nama penulis, dan unit kerja penulis.

2) Biodata Penulis;

3) Pernyataan Keaslian Tulisan;

4) Daftar Isi;

5) Ringkasan Isi Buku; dan

6) Daftar pustaka

3) Penyetoran proposal sebanyak tiga bundel

\section{Pengumuman Kelulusan Pendaftaran GSB UIN Alauddin Makassar}

Berdasarkan hasil seleksi dan verifikasi berkas pendaftar, maka selanjutnya pengumuman nama-nama yang lulus dalam seleksi proposal penyusunan buku karyailmiah yang kemudian di SK kan oleh Rektor UIN Alauddin Makassar.

Selanjutnya kepada mereka yang lolos seleksi dan verifikasi berkas untuk memasukan hal-hal berikut:

a. Memasukkan kontrak perjanjian penulisan buku antara penulis dan ketua panitia GSB UIN Alauddin Makassar.

b. Kontrak perjanjian tersebut dapat didownload pasa website http://www.uinalauddin.ac.id

c. Dalam kontrak, penulis (pihak kedua) menandatangani kontrak tersebut setelah menempelkan materai 6000 .

d. Kontrak yang telah ditandatangani diserahkan kepada panitia GSB UIN Alauddin Makassar (a/n Bapak Kusa, S.Ag.) di kantor LPM.

e. Penyerahan naskah buku sesuai batas waktu yang ditentukan (bagi mereka yang mendaftar dengan melampirkan naskah buku). Dan bagi mereka yang melampirkan proposal batas waktu juga ditentukan.

f. Sistematika naskah buku yang ditulis adalah:

I. Naskah buku yang ditulis terdiri atas 200-225 halaman;

II. Naskah buku diketik dengan ukuran buku yang akan dicetak, yaitu:

a. Di kertas (custom size) ukuran 14,5 cm (lebar) x 20,5 cm (tinggi); spasi 1 (single) lines;

b. Margin top $2 \mathrm{~cm}$, bottom $2 \mathrm{~cm}$, left $2 \mathrm{~cm}$, dan right $2 \mathrm{~cm}$. 
III. Naskah buku diketik dengan menggunakan font/huruf Garamond atau book antique, size 14 di judul bab, 12 di sub bab, dan 11 di dalam tulisan;

IV. Untuk tulisan Arab, seperti hadis dan al-Qur'an menggunakan font/huruf Traditional Arabic, size 18.

V. Naskah buku terdiri atas: (a) Halaman cover yang mencantumkan judul buku, dan nama lengkap penulis; (b) Kata Pengantar Penulis; (c) Daftar isi; (d) Daftar Tabel (kalau ada); (e) Daftar Gambar (kalau ada); (f) Bab I Pendahuluan (mencakup judul bab utama dan sub bab sebagai rincian dari bab tersebut); (g) Bab II (mencakup judul bab utama dan sub bab sebagai rincian dari bab tersebut); (h) Bab dst; (i) Riwayat Hidup dan Foto Penulis; dan (j) Executive Summary (Ringkasan Isi Buku) yang tidak melebihi dua halaman.

\section{Kontrak Perjanjian}

Dalam kontrak perjanjian yang dibuat antara pihak Pertama dalam hal ini UIN Alauddin Makassar oleh Prof. Dr. H. Ahmad M. Sewang, M.A., dengan pihak Kedua dalam hal ini penulis GSB UIN Alauddin Makassar yang atas nama pribadi penulis. Maka dengan ini sepakat untuk mengadakan kontrak perjanjian yang mencakup hal-hal seperti tercantum dalam pasal dibawah ini:

Pasal 1. Dasar

Kontrak Perjanjian ini di lakukan atas dasar saling menguntungkan dalam rangka pengembangan pendidikan tinggi di Indonesia khususnya UIN Alauddin Makassar.

Pasal 2. Tujuan

Kontrak Perjanjian ini bertujuan untuk melancarkan program Gerakan Seribu Buku UIN Alauddin Makassar yang nantinya bermuara pada peningkatan sumber daya manusia (SDM) di lingkungan kampus demi pencapaian Tri Dharma Perguruan Tinggi. Secara khusus, gerakan ini juga diharapkan nantinya dapat mendorong peningkatan kualitas dosen yang bermuara pada pencapaian posisi tenaga pendidik profesional yang merupakan tuntutan utama pada undang-undang guru dan dosen nomor 14 Tahun 2005.

Pasal 3. Tugas dan Wewenang

(1) Pihak pertama menyanggupi penerbitan naskah yang disiapkan oleh pihak kedua

(2) Pihak pertama menyanggupi honorarium kepada pihak kedua sejumlah Rp. 12. 500.000,- (Dua Belas Juta Lima Ratus Ribu Rupiah) termasuk pajak.

(3) Pihak kedua menyanggupi penyerahan naskah buku yang siap di cetak kepada pihak pertama selambat-lambatnya sesuai waktu yang ditentukan (bagi mereka yang mendaftar dengan melampirkan naskah buku). Sedangkan yang mendaftar dengan hanya melampirkan proposal maka batas akhir penyerahan naskah buku yang siap cetak selambat-lambatnya sesuai waktu yang telah ditentukan.

(4) Keterlambatan menyerahkan naskah buku dari waktu yang telah ditetapkan di atas dinyatakan mengundurkan diri.

(5) Hak cipta dalam program Gerakan Seribu Buku ini dimiliki oleh penulis.

(6) Jika buku yang ditulis ditemukan adanya plagiasi, maka panitia berhak untuk membatalkan keikutsertaannya dalam penulisan GSB selanjutnya.

(7) Penulis berhak menerima sebanyak 5 (lima) eksemplar. 
(8) Jika buku yang akan diterbitkan pihak UIN Alauddin Makassar ternyata telah di cetak dan di perbanyak lain maka penulis bertanggung jawab sepenuhnya jika terjadi keberatan atas hal itu.

(9) Sebelum dilakukan proses pencetakan penulis wajib melakukan review akhir.

Pasal 4. Penutup

(1) Segala perbedaan yang terjadi dalam kontrak ini, akan diselesaikan secara musyawarah.

(2) Perubahan terhadap isi kontrak perjanjian ini, hanya dapat dilakukan atas persetujuan kedua belah pihak sebagai addendum yang tidak terpisahkan dalam kontrak perjanjian ini.

Penyediaan buku-buku GSB UIN Alauddin Makassar tiap tahunnya telah mencapai 250 judul dari berbagai disiplin ilmu, di antaranya:

\begin{tabular}{|c|c|c|c|c|}
\hline No & Nama & Judul & Fakultas/Jurusan & Tahun \\
\hline 1 & $\begin{array}{l}\text { Muh. Quraisy Mathar, } \\
\text { S.Sos, M.Hum. }\end{array}$ & $\begin{array}{c}\text { Hubungan } \\
\text { promosi terhadap } \\
\text { layanan } \\
\text { perpustakaan }\end{array}$ & $\begin{array}{c}\text { Ilmu } \\
\text { Perpustakaan }\end{array}$ & 2011 \\
\hline 2 & $\begin{array}{l}\text { Prof. Dr. Arifuddin Ahmad, } \\
\text { M.Ag. }\end{array}$ & $\begin{array}{l}\text { Metodologi } \\
\text { pemahaman } \\
\text { hadis (kajian } \\
\text { ilmu ma'an al } \\
\text { hadis) }\end{array}$ & Tafsir Hadis & 2011 \\
\hline 3 & $\begin{array}{l}\text { Abd. Halim Talli, S.Ag, } \\
\text { M.Ag. }\end{array}$ & $\begin{array}{l}\text { Peradilan Islam } \\
\text { dalam sistem } \\
\text { peradilan di } \\
\text { Indonesia }\end{array}$ & Hukum & 2011 \\
\hline 4 & $\begin{array}{l}\text { Dr. Muhammad Sabri AR, } \\
\text { MA. }\end{array}$ & $\begin{array}{l}\text { Mistisme dalam } \\
\text { hal-hal "tak } \\
\text { tercakapkan" } \\
\text { perspektif } \\
\text { filsafat analitik }\end{array}$ & Pemikiran Islam & 2011 \\
\hline 5 & $\begin{array}{l}\text { Dr. Muljono Damopolii, } \\
\text { M.Ag. }\end{array}$ & $\begin{array}{c}\text { Pesantren } \\
\text { Modern IMMIM } \\
\text { pencetak muslim } \\
\text { modern }\end{array}$ & Pendidikan & 2011 \\
\hline 6 & $\begin{array}{l}\text { dr. Rini Fitriani, S.Ked, } \\
\text { M.Kes. }\end{array}$ & $\begin{array}{l}\text { Kesehatan } \\
\text { reproduksi }\end{array}$ & Kesehatan & 2011 \\
\hline 7 & Dr. Arifuddin, M.Ag. & $\begin{array}{c}\text { Metode dakwah } \\
\text { dalam } \\
\text { masyarakat }\end{array}$ & Dakwah & 2011 \\
\hline 8 & Drs. Amiruddin K, M.Ei. & Ekonomi dan & Ekonomi Islam & 2011 \\
\hline
\end{tabular}




\begin{tabular}{|c|c|c|c|c|}
\hline & & keuangan syariah & & \\
\hline 9 & $\begin{array}{l}\text { Muhammad Anshar Akil, } \\
\text { ST, M.Si. }\end{array}$ & $\begin{array}{c}\text { Teknologi } \\
\text { komunikasi dan } \\
\text { informasi } \\
\text { (tinjauan system, } \\
\text { perangkat, } \\
\text { jaringan, dan } \\
\text { dampak) }\end{array}$ & $\begin{array}{l}\text { Sains dan } \\
\text { teknologi }\end{array}$ & 2011 \\
\hline 10 & $\begin{array}{l}\text { Prof. Dr. H. A. Qadir } \\
\text { Gassing }\end{array}$ & Caracter building & Pendidikan & 2011 \\
\hline 11 & Himayah, S.S, MIMS. & $\begin{array}{c}\text { Katalogisasi } \\
\text { perpustakaan dan } \\
\text { informasi }\end{array}$ & $\begin{array}{c}\text { Ilmu } \\
\text { Perpustakaan }\end{array}$ & 2012 \\
\hline 12 & Drs. M. Jayadi, M.Ag. & $\begin{array}{l}\text { Metodologi } \\
\text { kajian hadist }\end{array}$ & Tafsir Hadis & 2012 \\
\hline 13 & $\begin{array}{l}\text { Dr. Abdillah Mustari, S.Ag, } \\
\text { M.Ag. }\end{array}$ & $\begin{array}{c}\text { Pengaruh } \\
\text { mazhab dalam } \\
\text { kodifikasi hukum } \\
\text { Islam di } \\
\text { Indonesia }\end{array}$ & Hukum & 2012 \\
\hline 14 & $\begin{array}{l}\text { Prof. Dr. H. Nihaya, } \\
\text { M.Hum. }\end{array}$ & $\begin{array}{c}\text { Pluralisme } \\
\text { pemikiran } \\
\text { Nurcholish } \\
\text { Madjid }\end{array}$ & Pemikiran Islam & 2012 \\
\hline 15 & $\begin{array}{l}\text { Dr. H. Syahruddin Usman, } \\
\text { M.Pd. }\end{array}$ & $\begin{array}{l}\text { Ilmu pendidikan } \\
\text { Islam }\end{array}$ & Pendidikan & 2012 \\
\hline 16 & $\begin{array}{l}\text { dr. Nurhira Abdul Kadir, } \\
\text { S.Ked. }\end{array}$ & $\begin{array}{l}\text { Promosi kesehatan } \\
\text { dalam pelayanan } \\
\text { kebidanan: prinsip } \\
\text { dasar dan } \\
\text { aplikasinya } \\
\end{array}$ & Kesehatan & 2012 \\
\hline 17 & $\begin{array}{l}\text { St. Rahmatiah, S.Ag, } \\
\text { M.Sos.I. }\end{array}$ & $\begin{array}{l}\text { Dakwah Islam di } \\
\text { Spanyol (suatu } \\
\text { analisis historis) }\end{array}$ & Dakwah & 2012 \\
\hline 18 & Jamaluddin Majid, SE, M.Si. & $\begin{array}{l}\text { Perekonomian } \\
\text { Indonesia } \\
\end{array}$ & Ekonomi Islam & 2012 \\
\hline 19 & $\begin{array}{l}\text { Mustikasari, } \quad \text { S.Kom, } \\
\text { M.Kom. }\end{array}$ & $\begin{array}{c}\text { Logika } \\
\text { informatika }\end{array}$ & $\begin{array}{l}\text { Sains dan } \\
\text { teknologi }\end{array}$ & 2012 \\
\hline 20 & $\begin{array}{l}\text { Irvan Muliyadi, S.Ag, S.S, } \\
\text { M.A. }\end{array}$ & $\begin{array}{c}\text { Dasar-dasar } \\
\text { kepustakawanan }\end{array}$ & $\begin{array}{c}\text { Ilmu } \\
\text { Perpustakaan }\end{array}$ & 2013 \\
\hline 21 & Burhanuddin Darwis, L.c, & Metodologi & Tafsir Hadis & 2013 \\
\hline
\end{tabular}




\begin{tabular}{|c|c|c|c|c|}
\hline & M.Th.I. & tekhrij hadist & & \\
\hline 22 & $\begin{array}{l}\text { Abdul Rahman Kanang, } \\
\text { S.Ag, M.Pd. }\end{array}$ & $\begin{array}{l}\text { Kapita selekta } \\
\text { hokum tata } \\
\text { Negara } \\
\text { kontemporer }\end{array}$ & Hukum & 2013 \\
\hline 23 & Dr. H. Barsihannor, M. Ag. & $\begin{array}{l}\text { Dialog tiga } \\
\text { mazhab besar } \\
\text { teologi Islam }\end{array}$ & Pemikiran Islam & 2013 \\
\hline 24 & Dr. Sitti Mania, M.Ag. & $\begin{array}{l}\text { Metodologi } \\
\text { penelitian } \\
\text { pendidikan dan } \\
\text { sosial }\end{array}$ & Pendidikan & 2013 \\
\hline 25 & Haeriah, S.Si, M.Si. & $\begin{array}{l}\text { Perhitungan } \\
\text { farmasi }\end{array}$ & Kesehatan & 2013 \\
\hline 26 & Drs. Muh. Anwar, M.Hum. & $\begin{array}{l}\text { Prinsip-prinsip } \\
\text { retorika dalam } \\
\text { berkomunikasi }\end{array}$ & Dakwah & 2013 \\
\hline 27 & $\begin{array}{l}\text { Dr. M. Wahyuddin Abdullah, } \\
\text { S.E, M.Si, Ak. }\end{array}$ & $\begin{array}{c}\text { Akuntansi } \\
\text { keuangan } \\
\text { adaptasi IFRS }\end{array}$ & Ekonomi Islam & 2013 \\
\hline 28 & Sriany Ersina, S.T,MT. & $\begin{array}{l}\text { Kajian ruang } \\
\text { publik kota } \\
\text { makassar }\end{array}$ & $\begin{array}{l}\text { Sains dan } \\
\text { teknologi }\end{array}$ & 2013 \\
\hline 29 & $\begin{array}{l}\text { Hildawati Almah, S.Ag, SS, } \\
\text { M.A. }\end{array}$ & $\begin{array}{l}\text { Bahan rujukan } \\
\text { perpustakaan } \\
\text { dan pusat } \\
\text { dokumentasi } \\
\text { informasi }\end{array}$ & $\begin{array}{c}\text { Ilmu } \\
\text { Perpustakaan }\end{array}$ & 2014 \\
\hline 30 & $\begin{array}{l}\text { Drs. Muhammad Yahya, } \\
\text { M.Ag. }\end{array}$ & $\begin{array}{l}\text { Metode kritik } \\
\text { hadist oleh } \\
\text { Nasiruddin al- } \\
\text { Albani: telaah } \\
\text { kitab silsilah al- } \\
\text { hadis al-daifah } \\
\text { wa al-maudhuah }\end{array}$ & Tafsir Hadis & 2014 \\
\hline 31 & Ahkam Jayadi, S.H, M.Hum. & $\begin{array}{l}\text { Memahami } \\
\text { tujuan hukum }\end{array}$ & Hukum & 2014 \\
\hline 32 & $\begin{array}{l}\text { Muhaemin Latif, M.Th.I, } \\
\text { M.Ed. }\end{array}$ & $\begin{array}{c}\text { Kritik nalar } \\
\text { pemikiran Islam }\end{array}$ & Pemikiran Islam & 2014 \\
\hline 33 & Dr. Syaharuddin Usman, & Belajar dan & Pendidikan & 2014 \\
\hline
\end{tabular}




\begin{tabular}{|c|l|c|c|c|}
\hline & M.Pd. & $\begin{array}{c}\text { pembelajaran } \\
\text { perspektif Islam }\end{array}$ & & \\
\hline 34 & $\begin{array}{l}\text { Muh. Anwar Hafid. Ns, } \\
\text { M.Kes. }\end{array}$ & $\begin{array}{c}\text { Asuhan } \\
\text { keperawan pada } \\
\text { system imun }\end{array}$ & Kesehatan & 2014 \\
\hline 35 & $\begin{array}{l}\text { Dr. Muh. Nurhidayat Said, } \\
\text { M.Ag. }\end{array}$ & $\begin{array}{c}\text { Dakwah dan } \\
\text { berbagai } \\
\text { aspeknya }\end{array}$ & Dakwah & 2014 \\
\hline 36 & Dr. Muslimin, M.Ag. & $\begin{array}{c}\text { Ekonomi } \\
\text { syariah: } \\
\text { paradigm, } \\
\text { pemikiran, dan } \\
\text { kelembagaannya }\end{array}$ & Ekonomi Islam & 2014 \\
\hline 37 & Wasilah, S.T, M.T. & $\begin{array}{c}\text { Arsitektur etnik } \\
\text { nusantara }\end{array}$ & $\begin{array}{c}\text { Sains dan } \\
\text { teknologi }\end{array}$ & 2014 \\
\hline
\end{tabular}

\section{PENUTUP}

Mengacu pada pembahasan yang telah dipaparkan sebelumnya maka, dapat diambil kesimpulan sebagai berikut:

Proses manajemen pengadaan buku GSB UIN Alauddin Makassar ada beberapa tahapan, yang dimulai dari: tahap pembentukan panitia GSB UIN Alauddin Makassar, pembukaan pendaftaran GSB UIN Alauddin Makassar, seleksi dan verifikasi berkas pendaftar GSB UIN Alauddin Makassar, pengumuman kelulusan pendaftaran GSB UIN Alauddin Makassar, dan tahap kontrak perjanjian. Tahapan manajemen pengadaan buku GSB UIN Alauddin Makassar menunjukkan sudah cukup baik dan terarah, akan tetapi masih perlu ada upaya-upaya evaluasi dan perbaikan, misalnya dari segi membangun hubungan kerjasama dan koordinasi di antara panitia, tim independen, dan penulis maupun evaluasi dan perbaikan yang sifatnya tekhnis. Mengingat buku-buku dan program GSB di UIN Alauddin Makassar dapat menunjang kebutuhan referensi dosen dan mahasiswa dalam pengembangan ilmu pengetahuan, serta dapat membangun iklim kepenulisan yang kondusif dikalangan penulis yaitu dosen dan mahasiswa, maka diharapkan agar program GSB di UIN Alauddin Makassar teerus menjadi program unggulan yang wajib. 


\section{DAFTAR PUSTAKA}

Ali, Sayuthi, Metodologi Penelitian Agama: Pendekatan Teori dan Praktek, Ed. I Cet. I; Jakarta: PT Raja Grafindo Persada, 2002

Almah, Hildawati. Pemilihan dan Pengembangan Koleksi Perpustakaan. Makassar: Alauddin University Press, 2012.

Arikunto, Suharsimi, dan Cepi S. Abdul Jabar. Evaluasi Program Pendidikan: Pedoman Teoritis Praktis Bagi Praktisi Pendidikan. Cet, I; Jakarta: Bumi Aksara, 2004.

Darmono, Manajemen dan Tata Kerja Perpustakaan Sekolah, Jakarta: Gramedia Pustaka Utama, 2001

Departemen Agama RI, Al-Qur'an dan Terjemahnya, Jakarta: Maghfirah Pustaka, 2006

Departemen Pendidikan dan Kebudayaan. Keputusan Menteri Pendidikan dan Kebudayaan Nomor 0103/O/1981, Tanggal 11 Maret 1981. Dikutip dalam Elin Rosalin. Pemanfaatan Perpustakaan dan Sumber Informasi (Bandung: Karsa Mandiri Persada, 2008.

Fattah, Nanang. Landasan Manajemen Pendidikan. Cet. X; Bandung: Remaja Rosdakarya, 2009.

Gomes, C. Faustino. Manajemen Sumber Daya Manusia. Yogyakarta: Andi Offset, 1997.

Hasibuan. Manajemen Dasar Pengerian dan Masalah. Cet. II; Bandung: Haji Masagung, 1990.

Irsan, "Pandangan Pustakawan UIN Alauddin Makassar terhadap Pelarangan BukuBuku Kiri di Era Orde Baru", Skripsi, Makassar: Fakultas Adab dan Humaniora, 2013

Koswara. Dinamika Informasi Dalam Era Global. Bandung: Pengurus Daerah Ikatan Pustakawan Indonesia Jawa Barat bekerjasama dengan Penerbit PT Remaja Rosdakarya, 1998.

Marbun B.N. Konsep Manajemen Indonesia, Jakarta: Bagian Publikasi Lembaga Pendidikan dan Pembinaan Manajemen, 1980.

Soeatminah. Perpustakaan Kepustakawanan dan Pustakawan. Yogyakarta: Kanisius, 1992.

Sudijono, Anas. Pengantar Evaluasi Pendidikan. Cet. III; Jakarta: Rajawali Press, 2009.

Sulistyo-Basuki, Pengantar Ilmu Perpustakaan (Jakarta: Gramedia Pustaka utama, 2000

Suprayogo, Imam, Metodologi Penelitian Sosial-Agama Cet. I; Bandung: PT Remaja Rosdakarya, 2001

Syafaruddin, Manajemen Lembaga Pendidikan Islam Jakarta: Ciputat Press, 2005

Usman, Husaini. Manajemen: Teori Praktek dan Riset pendidikan. Cet. II; Jakarta: Bumi Aksara, 2010.

Wahyu. Pedoman Penelitian Pendidikan. Bandung: Tarsito, 1996. 